\title{
Genetic risk factors in diabetic retinopathy
}

\author{
L. L. Stewart ${ }^{1,2}$, L. L. Field ${ }^{1,2}$, S. Ross ${ }^{3}$, R. G.McArthur ${ }^{1,2}$ \\ ${ }^{1}$ Alberta Children's Hospital, Calgary, Alberta, Canada \\ ${ }^{2}$ Department of Paediatrics, University of Calgary, Calgary, Alberta, Canada \\ ${ }^{3}$ Department of Medicine, University of Calgary, Calgary, Alberta, Canada
}

\begin{abstract}
Summary. Diabetic retinopathy is the leading cause of blindness in adults aged 30 to 65 years. However, $20 \%$ of the diabetic population does not develop significant retinopathy. To examine the influence of immune-related genetic factors on the development of diabetic retinopathy, we studied immunoglobulin allotypes in 102 subjects aged 8 to 20 years, who had had Type 1 (insulin-dependent) diabetes mellitus for 4.5 to 11 years (mean 7.3 years). HLA had been previously typed on 59 of these subjects. Retinopathy was assessed by expert review of retinal photographs. Among the 44 patients who had evidence of retinopathy, $33(75 \%)$ were $\mathrm{G} 2 \mathrm{~m}(23+)$, while among the 58 patients without retinopathy but with similar duration of disease, only $28(48 \%)$ were $\mathrm{G} 2 \mathrm{~m}(23+)(p=0.006)$. The HLA-DR types of patients with and without retinopathy were not significantly different.
\end{abstract}

We conclude that there is significant evidence of an association between $\mathrm{G} 2 \mathrm{~m}(23)$ at the locus encoding $\mathrm{IgG} 2$ subclass heavy chains and susceptibility to the development of diabetic retinopathy early in the clinical course of the disease. Our findings provide important independent confirmation of a previous report of association between $\mathrm{Gm}$ allotypes and predisposition to diabetic retinopathy. We are unable to determine if the $\mathrm{Gm}$ effect on development of retinopathy is due to the $\mathrm{G} 2 \mathrm{~m}(23)$ allotype itself, or due to genes that are closely linked to, and in linkage disequilibrium with, the locus encoding the $\mathrm{G} 2 \mathrm{~m}(23)$ allotype.

Key words: Genetic risk factors, retinopathy, immunoglobulin allotypes, $\mathrm{Gm}$, Km, HLA.
Diabetic retinopathy is a significant complication of both Type 1 (insulin-dependent) and Type 2 (non-insulin-dependent) diabetes mellitus. The prevalence of retinopathy is dependent on the duration of diabetes, being rare before 5 years but present in $95 \%$ of patients 15 years after diagnosis of diabetes [1]. Proliferative retinopathy occurs in $25 \%$ of patients at 15 years but increases to $67 \%$ at 35 years. Other risk factors reported to be associated with diabetic retinopathy include glycaemic control [2,3], hypertension, hyperlipidaemia, and genetic factors.

A number of papers have looked at genetic factors which may play a role in the development of retinopathy. Malone et al. [4] found an association between the DR3/DR4 heterozygote phenotype and retinopathy. Baker et al. [5] and $\mathbb{R}$ and et al. [6] found an association between DR4/DR0, DR3/DR0, and DRX/DRX antigens and proliferative diabetic retinopathy in non-myopic patients (where $X \neq 3$ or 4 , and 0 indicates homozygous or presence of blank allele). Sterky and Wall [7] and Dornan et al. [8] found an association between the DR4 antigen and retinopathy. More recently, Cruickshanks et al. [9] reported a significantly increased risk of pro- liferative retinopathy for diabetic patients who were DR3-DR4 + compared with those who were DR3-4-. Other groups have not found HLA-associated risk factors $[10,11]$. Fletcher et al. [10] found an association between the complement allotype C4B3 (in linkage disequilibrium with DR4), and retinopathy. Mijovic et al, [12] reported an increased prevalence of the Gm phenotype $(a, f, z ; n ; b l, g)$ in patients with retinopathy compared to patients without retinopathy matched for duration of disease. Gm phenotype has been shown to influence susceptibility to Type 1 diabetes (for review, see [13]). If $\mathrm{Gm}$ genetic factors were also associated with age of onset and therefore duration of diabetes, this could produce an artifactual Gm-retinopathy association. The same proviso applies to associations between HLA region genetic factors and retinopathy. It is therefore essential that studies aimed at elucidating factors associated with retinopathy compare groups with and without retinopathy which have similar disease duration. It is evident from the above that the influence of genetic factors on the development of retinopathy remains a controversial area. 
There is evidence that $\mathrm{IgG}$ is deposited in the walls of small blood vessels in diabetes [14]. IgG is a polypeptide composed of two heavy (gamma type) chains and two light chains (either kappa or lambda types). Each of the immunoglobulin chain types is encoded by separate sets of linked genes which are located on different chromosomes: the heavy chain genes are found on chromosome 14 , the kappa chain genes on chromosome 2, and the lambda chain genes on chromosome 22 [15]. The set of linked genes encoding each immunoglobulin chain type includes variable (antigen-binding) region genes and constant region genes. Allotypic markers are inherited antigenic determinants detected by immunological methods. $\mathrm{Gm}$ and $\mathrm{Km}$ allotypes are antigens found on the constant region of IgG gamma heavy chains and kappa light chains, respectively. There are four subclasses of IgG, which correspond to four possible gamma heavy chain subtypes, and these are encoded by four closely-linked genes. Each IgG subclass (IgG1 - IgG4) has a specific structure and immunological role. Allotypes $\mathrm{G} 1 \mathrm{~m}(1$, $2,3,17)$ are associated with IgG1 subclass only, G2m(23) with IgG2 subclass only, and G3 $\mathrm{m}(5,21)$ with $\operatorname{IgG} 3$ subclass only [15]. No allotypes have been found on IgG4 subclass gamma chains or on lambda light chains. A series of Gm allotypic markers constituting a gene complex and inherited as a block is referred to as a $\mathrm{Gm}$ haplotype. In Caucasians, the four common $\mathrm{Gm}$ haplotypes are $\mathrm{Gm}^{1,17221}$, $\mathrm{Gm}^{1,2,17 ; 21}, \mathrm{Gm}^{3 ; 5}$, and $\mathrm{Gm}^{3: 23 ; 5}[16]$. Thus, in Caucasians, a haplotype is either positive for $\mathrm{G} 1 \mathrm{~m}(1, \pm 2,17)$ or $\mathrm{G} 1 \mathrm{~m}(3)$ at the locus encoding IgG1 subclass chains, either positive or negative for $\mathrm{G} 2 \mathrm{~m}(23)$ at the locus encoding $\mathrm{IgG} 2$ subclass chains (there is no antigenic determinant on the G2m(23)-negative molecule), and either positive for $\mathrm{G} 3 \mathrm{~m}(21)$ or $\mathrm{G} 3 \mathrm{~m}(5)$ at the locus encoding IgG3 subclass chains. The alternate antigenic allotypes for kappa immunoglobulin light chains are $\mathrm{Km}(1)$ and $\mathrm{Km}(3)$. Caucasians are either positive for $\mathrm{Km}(1)$ or $\mathrm{Km}(3)$ or heterozygous for both.

The present study was undertaken to assess the relationship between genetic factors and the development of early retinopathy in children with Type 1 diabetes, particularly genetic factors of immunoglobulins ( $\mathrm{Gm}$ and $\mathrm{Km}$ ).

\section{Subjects and methods}

\section{Subjects}

The present study comprised 102 children of European ancestry who were followed-up by the Alberta Children's Hospital Diabetes Clinic. This included 91 patients from a previously-defined group ascertained to examine the relationship between puberty and retinopathy and an additional 11 patients added to the present study to increase the sample size. Children were selected for the puberty study such that the mean duration of diabetes was similar in pre-pubertal and pubertal groups. This selection was done prior to any testing. The present study group ranged in age from 8 to 20 years and had diabetes for 4.5 to 11 years. In order to determine $\mathrm{Gm}$ allotype frequencies in the general population, we used control subjects consisting of 126 randomly-selected Calgary Red Cross blood donors. Informed consent for studies of genetic factors in diabetes was obtained from the subjects or (for those under 18 years old) their parents/guardians.

\section{Evaluation of patients}

The degree of retinopathy was assessed by retinal photography done through the Southern Alberta Study of Diabetic Retinopathy (SASDR). During each patient appointment, blood pressure (BP) was measured and blood was drawn to assess the lipid profile, haemoglobin $\mathrm{A}$, and C-peptide level. The eyes were dilated and multiple stereographic photographs were taken of each eye. The photographs were sent to Wisconsin and viewed by retinal specialists who were unaware of the patient's history. Diabetic retinopathy was graded using the Airlie-House classification [2] and subjects with any evidence of retinopathy were scored as positive for presence of retinopathy.

Long-term glycaemic control was assessed by obtaining the mean glycated haemoglobin for each patient. Eighty-eight percent of the children had more than eight measurements done from the time of diagnosis to the time of retinal photographs. Total glycated haemoglobin was measured by a column-affinity technique using the Glyc-Affin GHb Kit [17]. The normal non-diabetic values in our laboratory are $4-8 \%$.

$\mathrm{Gm}, \mathrm{Km}$, and HLA typing of 59 patients had been previously done in Dr. L. Field's laboratory as part of her continuing studies of the genetics of susceptibility to Type 1 diabetes. For the remaining 43 patients, only $\mathrm{Gm}$ and $\mathrm{Km}$ typing was performed. Typing for allotypes $\mathrm{G} 1 \mathrm{~m}(1), \mathrm{G} 1 \mathrm{~m}(2), \mathrm{G} 1 \mathrm{~m}(3), \mathrm{G} 1 \mathrm{~m}(17), \mathrm{G} 2 \mathrm{~m}(23), \mathrm{G} 3 \mathrm{~m}(5)$, and $\mathrm{G} 3 \mathrm{~m}(21)$ was done via the haemagglutination-inhibition technique using naturally occurring anti-Gm antibodies. A similar method was used for $\mathrm{Km}(1)$ typing $[18,19]$. HLA-A, B and DR types were determined by standard lymphocytotoxicity assay using Terasaki and Canadian Red Cross microtitre plates [20].

All the children had BP measured on four occasions. The mean BP was compared to norms $[21,22]$ and a percentile was assigned. This allowed a more accurate assessment of hypertension in children of various ages.

Lipid profiles, HDL and total cholesterol were assessed and compared to norms for age. Pubertal status was assessed by Tanner staging as prepubertal (Tanner I) or pubertal (Tanner IV or V) [23, 24].

\section{Statistical analysis}

Tables comparing frequencies of $\mathrm{Gm}$ phenotypes, $\mathrm{Gm}$ allotypes, HLA antigens and $\mathrm{Km}$ allotypes in patients subdivided by retinopathy status were constructed and analysed via chi-square testing, using SAS (Statistical Analysis System) computer software. Patients subdivided by retinopathy status and by $\mathrm{G} 2 \mathrm{~m}(23)$ status were compared with respect to duration, glycated haemoglobin, insulin dose, BP and cholesterol level using the two sample $t$-test, and were compared with respect to pubertal status using the chi-square test.

\section{Results}

The frequencies of the Gm phenotypes in a control population of healthy Calgary Red Cross blood donors is shown in Table 1 . The relationship between retinopathy and $\mathrm{Gm}$ phenotypes is also presented in Table 1. Patients with retinopathy had a higher frequency of the $\mathrm{Gm}$ $(1,3,17 ; 23 ; 5,21)$ phenotype than patients without retinopathy $(p=0.024)$. This is the same Gm phenotype which was found to be increased in patients with retinopathy in a previous study [12]. For many of the less common Gm phenotypes, there were few patients, making the results of the statistical analyses questionable. Unfortunately, it is difficult to collapse phenotypic categories in a meaningful way. To further analyse the $\mathrm{Gm}$ effect, we therefore 
Table 1. Frequencies of $\mathrm{Gm}$ phenotypes in healthy Calgary Red Cross control subjects, and in patients with and without retinopathy

\begin{tabular}{|c|c|c|c|c|c|c|}
\hline Gm phenotype & & $\begin{array}{l}\text { A: Healthy } \\
\text { Red Cross } \\
\text { control subjects }\end{array}$ & $\begin{array}{l}\text { B: Patients } \\
\text { with } \\
\text { retinopathy }\end{array}$ & $\begin{array}{l}\text { C: Patients } \\
\text { without } \\
\text { retinopathy }\end{array}$ & $\chi^{2}(\mathrm{~B}$ vs $\mathrm{C})$ & $p^{a}$ \\
\hline Numeric & Alphameric & & & & & \\
\hline $\begin{array}{l}3 ; 5 \\
1,3,17 ; 5,21 \\
1,2,3,17 ; 5,21 \\
1,17 ; 21 \\
1,2,17 ; 21 \\
3 ; 23 ; 5 \\
1,3,17 ; 23 ; 5,21^{\mathrm{b}} \\
1,2,3,17 ; 23 ; 5,21\end{array}$ & $\begin{array}{l}\text { f;bl } \\
\text { a,f,z;bl,g } \\
\text { a,x,f,z;bl,g } \\
\text { a,z;g } \\
\text { a,x,z;g } \\
\text { f;n;bl } \\
\text { a,f,z;n;bl,g } \\
\text { a,x,f,z;n;bl,g }\end{array}$ & $\begin{array}{c}12(9.5 \%) \\
13(10.3 \%) \\
1(0.8 \%) \\
11(8.7 \%) \\
3(2.4 \%) \\
47(37.3 \%) \\
30(23.8 \%) \\
9(7.1 \%)\end{array}$ & $\begin{array}{c}3(6.8 \%) \\
4(9.1 \%) \\
1(2.3 \%) \\
2(4.5 \%) \\
1(2.3 \%) \\
15(34.1 \%) \\
11(25.0 \%) \\
7(15.9 \%)\end{array}$ & $\begin{array}{c}6(10.3 \%) \\
10(17.2 \%) \\
2(3.4 \%) \\
4(6.9 \%) \\
8(13.8 \%) \\
17(29.3 \%) \\
5(8.6 \%) \\
6(10.3 \%)\end{array}$ & 5.075 & $\begin{array}{l}\text { NS } \\
\text { NS } \\
\text { NS } \\
\text { NS } \\
\text { NS } \\
\text { NS } \\
0.024 \\
\text { NS }\end{array}$ \\
\hline $1,2,3,17 ; 23 ; 5,21$ & Total & 126 & 44 & 58 & & \\
\hline
\end{tabular}

${ }^{a}$ NS, Not significant at 0.05 level

${ }^{\circ}$ Phenotype increased in frequency in Type 1 patients with retinopathy in Mijovic et al. [12]

Table 2. Frequencies of $\operatorname{IgG}$ allotypes in patients with and without retinopathy

\begin{tabular}{|c|c|c|c|c|c|}
\hline IgG allotype & $\begin{array}{l}\text { Patients } \\
\text { with } \\
\text { retinopathy } \\
(n=44)\end{array}$ & $\begin{array}{l}\text { Patients } \\
\text { without } \\
\text { retinopathy } \\
(n=58)\end{array}$ & $\chi^{2}$ & \multicolumn{2}{|l|}{$p$} \\
\hline \multicolumn{2}{|c|}{$\begin{array}{l}\text { 1) Red Cross control subjects } \\
\text { 2) All diabetic patients } \\
\text { 3) Diabetic patients with retinopathy } \\
\text { 4) Diabetic patients without retinopathy }\end{array}$} & & $\begin{array}{l}86(68 \%) \\
61(60 \%) \\
33(75 \%) \\
28(48 \%)\end{array}$ & $\begin{array}{l}40(32 \%) \\
41(40 \%) \\
11(25 \%) \\
30(52 \%)\end{array}$ & $\begin{array}{r}126 \\
102 \\
44 \\
58\end{array}$ \\
\hline
\end{tabular}

1) vs 2 ): $\chi^{2}=1.76$, not significant

1) vs 3): $\chi^{2}=0.71$, not significant

1) vs 4 ): $\chi^{2}=6.73, p=0.009$

3) vs 4$): \chi^{2}=7.43, p=0.006$

Table 3. Clinical data on patients positive and negative for $\mathrm{G} 2 \mathrm{~m}(23)$ and on patients with and without retinopathy

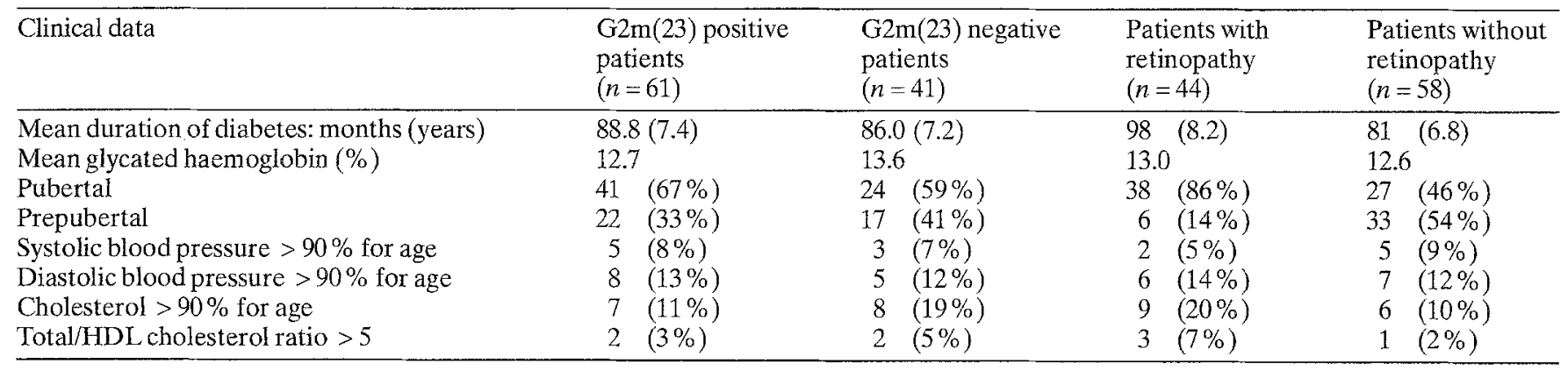

elected to consider the $4 \mathrm{Gm}$ allotypes, $\mathrm{G} 1 \mathrm{~m}(1), \mathrm{G} 1 \mathrm{~m}(2)$, G2 $\mathrm{m}(23)$ and G3 $\mathrm{m}(5)$, separately. These four key allotypes allow differentiation between the four common $\mathrm{Gm}$ haplotypes, $\mathrm{Gm}^{1,17 ; 21}, \mathrm{Gm}^{1,2,17 ; 21}, \mathrm{Gm}^{3 ; 23 ; 5}$ and $\mathrm{Gm}^{3 ; 5}$. $\mathrm{G} 1 \mathrm{~m}(1,17)$ and $\mathrm{G} 3 \mathrm{~m}(21)$ are inherited as a unit, so an individual is either positive or negative for all three allotypes. Differentiation between the $\mathrm{Gm}^{1,17 ; 21}$ and $\mathrm{Gm}^{1,2,17 ; 21}$ haplotypes in a $\mathrm{G} 1 \mathrm{~m}(1+)$ individual is accomplished by examining the G1 $\mathrm{m}(2)$ allotype. Similarly, G1 $\mathrm{m}(3)$ and $\mathrm{G} 3 \mathrm{~m}(5)$ are inherited together, so a person is either positive or negative for both allotypes. The $\mathrm{Gm}^{3: 5}$ and $\mathrm{Gm}^{3 ; 23 ; 5}$ haplotypes can be differentiated by assessing the $\mathrm{G} 2 \mathrm{~m}(23)$ allotype in a person who is positive for $\mathrm{G} 3 \mathrm{~m}(5)$.

Table 2 shows the results of analysing the frequencies of the four key $\mathrm{Gm}$ allotypes in patients with and without retinopathy. There was a significant positive association of $\mathrm{G} 2 \mathrm{~m}(23)$ with retinopathy $(p=0.006)$. In the group with retinopathy, the $\mathrm{G} 2 \mathrm{~m}(23)$ allotype was present at a frequency of $75 \%$, while in those without retinopathy, it was present at a much decreased frequency, $48 \%$. The frequency of $\mathrm{G} 2 \mathrm{~m}(23)$ in the control population was $68 \%$; this was not significantly different from that seen in all 
Table 4. Relationship between retinopathy and HLA-DR

\begin{tabular}{lcc}
\hline DR type & $\begin{array}{l}\text { Patients } \\
\text { with } \\
\text { retinopathy }\end{array}$ & $\begin{array}{l}\text { Patients } \\
\text { without } \\
\text { retinopathy }\end{array}$ \\
\hline DR3 $+4+$ & $5(25 \%)$ & $16(41 \%)$ \\
DR3 $+4-$ & $3(15 \%)$ & $8(20 \%)$ \\
DR3 $-4+$ & $9(45 \%)$ & $11(28 \%)$ \\
DR3 $-4-$ & $3(15 \%)$ & $4(10 \%)$ \\
Total & $20(100 \%)$ & $39(100 \%)$ \\
\hline
\end{tabular}

$\chi^{2}=2.52(3 d f), p=0.47$

diabetic patients $(60 \%)$, or in diabetic patients with retinopathy $(75 \%)$, but was significantly different from that seen in diabetic patients without retinopathy (48\%) (Table 2). When the diabetic patients were broken down into pubertal and prepubertal groups, there was increased G2m(23) in those with retinopathy within each group (data not shown).

There was no significant association of retinopathy with $\mathrm{G} 1 \mathrm{~m}(1)$ or $\mathrm{G} 1 \mathrm{~m}(2)$ allotypes (Table 2). Using chisquare analysis, the increased prevalence of G3m(5) in patients with retinopathy was significant $(p=0.019)$, however this was probably secondary to the $\mathrm{G} 2 \mathrm{~m}(23)$ effect: $\mathrm{G} 3 \mathrm{~m}(5)$ and $\mathrm{G} 2 \mathrm{~m}(23)$ occur together in three of the six Gm phenotypes which are positive for G3m(5) (representing the presence of the $\mathrm{Gm}^{3: 23 ; 5}$ haplotype) and only these three $\mathrm{G} 3 \mathrm{~m}(5+)$ phenotypes had an increased prevalence in patients with retinopathy compared to patients without retinopathy (see first 3 and last $3 \mathrm{Gm}$ phenotypes in Table 1).

The prevalence of retinopathy increases with the duration of diabetes and with higher glycated haemoglobin. Table 3 summarizes data comparing G2 $\mathrm{m}(23)$ positive and negative patients with respect to these and other retinopathy risk factors. The two groups were similar: no variable showed a significant difference between groups. Table 3 also summarizes clinical data on diabetic patients with and without retinopathy, showing the two groups were similar for all variables except pubertal status. The latter observation will be discussed in a subsequent paper.

There was no association between retinopathy and HLA-DR types in our small subsample of 59 diabetic patients (Table 4). There also was no association between retinopathy and $\mathrm{Km}$ allotypes: $20 \%$ (9 of 44) of patients with retinopathy were $\mathrm{Km}(1+)$, compared to $16 \%$ (9 of 58) of patients without retinopathy.

\section{Discussion}

There was a significant association between possession of the immunoglobulin allotype $\mathrm{G} 2 \mathrm{~m}(23)$ and development of retinopathy in children with a 4.5 to 11 -year (mean 7.3year) history of Type 1 diabetes. Patients with retinopathy had a higher frequency of $\mathrm{G} 2 \mathrm{~m}(23)$ than those without retinopathy, suggesting that either $\mathrm{G} 2 \mathrm{~m}(23)$ is associated with increased susceptibility to retinopathy, or lack of G2 $\mathrm{m}(23)$ is associated with protection against retinopathy. The expected (normal population) allotype frequency for $\mathrm{G} 2 \mathrm{~m}(23)$ was $68 \%$. The patients with retino- pathy had a similar G2 $\mathrm{m}(23)$ allotype frequency of $75 \%$, while the patients without retinopathy had a frequency of $48 \%$. This implies a protective effect of Gm types negative for the $\mathrm{G} 2 \mathrm{~m}(23)$ allotype - that is, individuals lacking an antigenic determinant on their IgG2 subclass immunoglobulins appear to be protected against development of retinopathy. The two children with significant retinopathy (maculopathy in one case and preproliferative retinopathy in the other) were both $\mathrm{G} 2 \mathrm{~m}(23+)$. The $\mathrm{G} 2 \mathrm{~m}(23)$ effect was independent of other risk factors. The patients positive for the $\mathrm{G} 2 \mathrm{~m}(23)$ allotype actually had better mean glycated haemoglobin values despite having a higher prevalence of diabetic retinopathy than those who were G2m(23-). Importantly, the mean duration of diabetes was similar in patients with and without G2m(23). The Gm-retinopathy relationship held for both the pubertal and prepubertal groups (data not shown). There was also an association between diabetic retinopathy and the phenotype $\mathrm{Gm}(1,3,17 ; 23 ; 5,21)$. This phenotype corresponds to the genotype $\mathrm{Gm}^{3 ; 23 ; 5} / \mathrm{Gm}^{1,17 ; 21}$. The other Gm phenotypes were not associated with significantly increased risk of diabetic retinopathy; however, some of the phenotypes were uncommon and accurate statistical analysis was not possible due to the small sample size. There was no significant association between diabetic retinopathy and $\mathrm{G} 1 \mathrm{~m}(1)$ or $\mathrm{G} 1 \mathrm{~m}(2)$ allotypes. The G3m(5) association could be completely accounted for by the fact that $\mathrm{G} 2 \mathrm{~m}(23)$ is always co-inherited with $\mathrm{G} 3 \mathrm{~m}(5)$, via the $\mathrm{Gm}^{3 ; 23 ; 5}$ haplotype. We found no HLADR or Km association with diabetic retinopathy.

Mijovic et al. [12] found an association between the $\mathrm{Gm}$ phenotype $(a, f, z ; n ; b l ; g)$, which is the same as $\operatorname{Gm}(1,3$, $17 ; 23 ; 5,21)$, and microangiopathy in an adult population with Type 1 diabetes. The same group of investigators found an association of retinopathy with $\mathrm{Gm}(\mathrm{a}, \mathrm{x}, \mathrm{f}, \mathrm{z} ; \mathrm{n} ; \mathrm{bl}, \mathrm{g})$ [equivalent to $\operatorname{Gm}(1,2,3,17 ; 23 ; 5,21)] 7$ years after diagnosis but not at 10 years after diagnosis, in Type 2 diabetic subjects [25]. Both of these phenotypes are $G 2 m(23+)$. On reviewing the data of Mijovic et al. [12], there appears to be no association between the $\mathrm{G} 2 \mathrm{~m}(23)$ allotype and retinopathy in their entire (unmatched) group of diabetic subjects $\left(\chi^{2}=0.256, p=0.6\right)$. The frequency of the $\mathrm{G} 2 \mathrm{~m}(23)$ allotype in patients without retinopathy in the study by Mijovic et al. was $62 \%$ vs $48 \%$ in our study. This may have occurred because Mijovic et al. included patients with a short duration of diabetes (1-4 years) in the unmatched group without retinopathy. Patients with short disease duration have been shown to have a low prevalence $(5 \%)$ of retinopathy [1]. The unmatched groups with and without retinopathy in the study by Mijovic et al. differed with respect to duration of diabetes, which may explain the contrast between the results of their study and those of the present study (they found an association with a G2 $\mathrm{m}(23+$ ) phenotype and we found the strongest association with the $\mathrm{G} 2 \mathrm{~m}(23)$ allotype). Retinopathy was assessed clinically in the study by Mijovic et al., which is not as accurate as using retinal photographs reviewed by retinal specialists [26]. This may also have contributed to the differing results of the two studies.

There is evidence that proteins, including immunoglobulins, accumulate in the matrix lining the walls of small 
blood vessels in diabetic subjects. The amount of IgG cross-linked to the glomerular basement membrane is five times higher in diabetic than non-diabetic rats [14]. IgG binds preferentially to collagen and basement membranes which contain advanced glycated end-products (AGE) [14]. Brownlee et al. [27] have reviewed a model explaining the association of hyperglycaemia with diabetic complications based on the formation of AGE. Prolonged hyperglycaemia results in irreversible cross-linkage of collagen containing AGE. Immunoglobulins bind to the collagen-AGE complex, increasing attachment sites for other proteins and expanding the matrix. Macrophages have receptors for collagen with AGE and release monokines, tumour necrosis factor and interleukin-1. These monokines can initiate thrombus formation, cause increased vascular permeability, stimulate production of type IV collagen, and stimulate endothelial, fibrocyte and mesangial proliferation. There is also production of collagenase; however, glomerular basement membrane that is cross-linked with $\mathrm{AGE}$ is more resistant to digestion with proteases. The net balance favours accumulation of AGE. Monnier et al. [28] found an association between the amount of non-enzymatically glycated collagen proteins, as measured by fluorescent products in a stain biopsy, and the severity of diabetic retinopathy. There may be a difference between IgG2 subclass antibodies which are positive and negative for $\mathrm{G} 2 \mathrm{~m}(23)$ in their affinity for collagen with AGE, thus resulting in a difference in the amount of matrix lining the vessel walls. This may explain the $\mathrm{G} 2 \mathrm{~m}(23)$ association with diabetic retinopathy. It is also possible that a locus involved in the pathogenesis of diabetic retinopathy is linked to, and in disequilibrium with, the locus encoding $\mathrm{G} 2 \mathrm{~m}(23)$.

Studies have suggested that different Gm allotypes have different immunologic functions. $\mathrm{G} 2 \mathrm{~m}(23+)$ individuals have elevated levels of $\operatorname{IgG} 2$ and $\operatorname{IgG} 4$ [29]. Antibodies to dextran, levan, techoic acid and group A streptococcus are $\operatorname{IgG} 2, \mathrm{G} 2 \mathrm{~m}(23+)$ individuals have enhanced antibody responses to encapsulated micro-organisms [30]. There are a number of studies which show an association between $\mathrm{Gm}$ allotypes and autoimmune diseases. Nakao et al. [31] found an association between the $\operatorname{Gm}(1,2 ; 13,15,16,21)$ phenotype and the presence of insulin antibodies in Japanese Type 1 diabetic patients. Nakao et al. [32] also found an association between the G1 $\mathrm{m}(2)$ allotype and Hashimoto's thyroiditis, Graves disease and systemic lupus erythematosus (SLE). Whittingham et al. [33] showed the risk of developing SLE was significantly increased if both HLA-B8 and the heterozygous Gm phenotype $(\mathrm{a}, \mathrm{f}, \mathrm{x} ; \mathrm{b}, \mathrm{g})$ were present. We have evidence that $\mathrm{Gm}$ region genes influence susceptibility to Type 1 diabetes indirectly through interaction with HLA region genes and T-cell receptor beta chain region genes $[13,34$, 35].

Fletcher et al. [10] found an association of retinopathy with the C4 B3 complement allotype but not with HLA$\mathrm{DR}$ antigens. The C4B3 complement allele is in disequilibrium with HLA-DR4. Mijovic et al. [12] found that the $\mathrm{Gm}$ and complement effects on diabetic retinopathy were additive, rather than interactive, indicating that the two effects operated through independent mechanisms.
We found no HLA association with diabetic retinopathy in our subset of 59 HLA-typed patients. However, it should be noted that given the small numbers of HLAtyped diabetic subjects, our study has limited power to detect HLA differences between patients with and without retinopathy. Our negative finding is supported by other laboratories $[10,36,37]$. However, several other groups of investigators have reported some kind of association between retinopathy and HLA [4-9]. Thus, there is no conclusive and consistent evidence that major histocompatibility antigens play a role in diabetic retinopathy. The weak associations between DR4 antigens and retinopathy may well result from an effect of genes in linkage disequilibrium with HLA-DR antigens. The duration of diabetes was not controlled for in many studies, therefore the weak HLA associations might also be due to the possible earlier onset of Type 1 diabetes in DR4 patients suggested by some studies [38]. However, our studies do not support an association between DR4 and an earlier onset of diabetes.

In conclusion, we have identified a genetic factor that is associated with the development of diabetic retinopathy in patients who have had Type 1 diabetes for an average of 7.3 years. Possession of this genetic factor is not related to duration of diabetes; thus, the association of this genetic factor with retinopathy is not secondary to an effect of the genetic factor on duration or age of onset of diabetes. Although it has been shown that metabolic control influences the development of microvascular disease $[2,3]$, it now appears very probable that an immunogenetic component is also involved in the pathogenesis of retinopathy. Elucidation of the mechanism whereby immunoglobulin allotypes (or products of genes near the $\mathrm{Gm}$ loci) influence development of retinopathy will require intensive research. Identification of a subset of patients who are genetically more susceptible to developing retinopathy will enable us to: a) emphasize to those patients the importance of excellent glycaemic control in delaying microvascular disease, and b) target these patients for intervention when new methods of treating/preventing retinopathy are developed.

Acknowledgements. We wish to acknowledge the Canadian Red Cross which generously provided HLA typing trays, and the expert technical assistance of R. Tobias and E.Swiergala. This project was funded by the Medical Research Council of Canada (grant \# 7910 to LLF) and by the National Health Research Development Program of Canada (grant to SR). Dr. Field is an Alberta Heritage Medical Scientist and Dr. Stewart was supported by a Postdoctoral Clinical Fellowship from the Julia McFarlane Diabetes Centre at the University of Calgary. The excellent secretarial assistance of Ms. R. Hodorek is gratefully acknowledged.

\section{References}

1. Klein R, KIein BEK, Moss SE, Davis MD, DeMets DL (1984) The Wisconsin epidemiologic study of diabetic retinopathy. II. Prevalence and risk of diabetic retinopathy when age at diagnosis is less than 30 years. Arch Ophthalmol 102: $520-526$

2. Klein R, Klein BEK, Moss SE, Davis MD, DeMets DL (1988) Glycosylated hemoglobin predicts the incidence and progression of diabetic retinopathy. JAMA 260: 2864-2871

3. Doft BH, Kingsley LA, Orchard TJ, Kuller L, Drash A, Becker D (1984) The association between long-term diabetic control and early retinopathy. Ophthalmology 91: 763-769 
4. Malone JF, Gizzard WS, Espinoza LR, Achenbach RE, Van Cader TC (1984) Risk factors for diabetic retinopathy in youth. Pediatrics 73: 756-761

5. Baker RS, Rand LI, Krolewski AS, Maki T, Warram JH, Aiello LM (1986) Influence of HLA-DR phenotype and myopia on the risk of nonproliferative and proliferative diabetic retinopathy. Am J Ophthmol 102: 693-700

6. Rand LW, Krolewski AS, Aiello LM, Warram JH, Baker RS, Maki T (1985) Multiple factors in the prediction of risk of proliferative diabetic retinopathy. N Engl J Med 313: 1433-1438

7. Sterky G, Wall S (1986) Determinants of microangiopathy in growth-onset diabetes with special reference to retinopathy and glycemic control. Acta Paediatr Scand 327 [Suppl]: 5-45

8. Dornan TL, Ting A, McPherson CK et al. (1982) Genetic susceptibility to the development of retinopathy in insulin-dependent diabetes. Diabetes 31: 226-231

9. Cruickshanks KJ, Vadheim CM, Moss SE et al. (1992) Genetic marker associations with proliferative retinopathy in persons diagnosed with diabetes before $30 \mathrm{yr}$ of age. Diabetes 41: 879-885

10. Fletcher JA, Mijovic C, Barnett A et al. (1987) HLA and C4 polymorphism in diabetic microangiopathy. Diabetes Res 4: $101-102$

11. Barbosa J, Saner B (1984) Do genetic factors play a role in the pathogenesis of diabetic microangiopathy ? Diabetologia 27: 487492

12. Mijovic C, Fletcher JA, Bradwell ARE, Barrett AH (1986) Phenotypes of heavy chains of immunoglobulins in patients with diabetic microangiopathy: evidence for an immunogenetic predisposition. BMJ 292: 433-435

13. Field LL (1991) Non-HLA region genes in insulin dependent diabetes mellitus. Ballieres Clin Endocrinol Metab 5: 413-438

14. Brownlee M, Pongar S, Cerami A (1983) Covalent attachment of soluble proteins by nonenzymatically glycosylated collagen. I Exp Med 158: 1739-1744

15. Litwin SD (1989) Immunoglobulin allotypes. In: Litwin SD (ed) Human immunogenetics basic principles and clinical relevance, 2 nd edn. Macel Deltna Inc., New York, pp 202-236

16. Fudenberg HH, Pink JRL, Wang A-C, Ferrara (eds) (1984) Basic immunogenetics 3 rd edn. Oxford University Press, New York. pp 46-101

17. Willey DO, Rosenthal MA, Caldwell S (1984) Glycosylated hemoglobin and plasma glycoprotein assays by affinity chromatography. Diabetologia 27:56-58

18. Wegman AC, Smithies O (1965) A simple haemagglutination system requiring small amounts of red cells and antibodies. Transfusion 6: 67-73

19. Grubb R, Laurell AB (1956) Heredity serological human serum groups. Acta Pathol Microbiol Scand 39:390

20. Terasaki PI, Bernoco D, Park MS, Ozturk G, Iwaki Y (1978) Microdroplet testing for HLA-A, $-\mathrm{B},-\mathrm{C}$, and -D antigens. Am J Clin Pathol 69: 103-120

21. Lauer RM, Barns Tl, Clarke WK (1985) Assessing children's blood pressure - consideration of age and body size: The Muscatine Study. Pediatrics 76: 1081-1090

22. Horran MJ et al. (1987) Report of the second task force on blood pressure control in children - 1987 task force on blood pressure control in children. Pediatrics 79: 1-25

23. Marshall WA, Tanner JM (1969) Variations in the pattern of pubertal changes in girls. Arch Dis Child 44: 291-303
24. Marshall WA, Tanner JM (1970) Variations in pattern of pubertal changes in boys. Arch Dis Child 45: 13-23

25. Baldwin RN, Mijovic C, Fletcher J, Bradwell ARE, Barnett AH, Hockaday TDR (1988) Immunoglobulin heavy chain phenotypes and background retinopathy in non-insulin dependent diabetes. BMJ 297: 1104-1105

26. Sussman EJ, Tsiaras WG, Sopar MA (1982) Diagnosis of diabetic eye disease. JAMA 247:3231-3234

27. Brownlee M, Cerami A, Vlassara H (1988) Advanced glycosylation end products in tissue and the biochemical basis of diabetic complications. N Eng J Med 318: 1315-1321

28. Monnier V, Vishwanath V, Frank KE, Elmets CA, Dauchot P, Kohn RR (1986) Relation between complications of type 1 diabetes mellitus and collagen-linked fluorescence. $\mathrm{N}$ Engl J Med 314: 403-408

29. Steinberg AG, Morell AS, Skvaril F, Van Loghem E (1973) The effect of $\mathrm{Gm}(23)$ on the concentration of IgG2 and IgG4 in normal human serum. J Immunol 110: 1642-1645

30. Ambrosino D, Schffman G, Gotschlich E et al. (1985) Correlation between $\mathrm{G} 2 \mathrm{~m}(\mathrm{n})$ immunoglobulin allotype and human antibody response and susceptibility to polysaccharide encapsulated bacteria. J Clin Invest 75: 1935-1942

31. Nakao Y, Matsumoto H, Miyazaki T et al. (1981) IgG heavychain $(\mathrm{Gm})$ allotypes and immune response to insulin in insulinrequiring diabetes mellitus. N Engl J Med 304: 407-409

32. Nakao Y, Matsumoto H, Miyuzuki T, Farid NR (1982) IgG heavy chain allotypes $(\mathrm{Gm})$ in atrophic and goitrous thyroiditis. J Immunogenet 9: 311-316

33. Whittingham S, Mathews JD, Schandfield MS, Tait BD, Mack JR (1983) HLA and Gm genes in systemic lupus erythematosus. Tissue Antigens 21: 50-57

34. Field LL, McArthur RG (1987) The genetics of susceptibility to insulin-dependent diabetes mellitus - possible new markers. Clin Invest Med 10: 431-443

35. Field LL, Stephure DK, McArthur RG (1991) Interaction between T-cell receptor beta chain and immunoglobulin heavy chain region genes in susceptibility to insulin-dependent diabetes mellitus. Am J Hum Genet 49: 627-634

36. Bodansky H, Wolfe E, Cudworth A et al. (1982) Genetic and immunologic factors in microvascular disease in type 1 insulin-dependent diabetes. Diabetes 31: 70-74

37. Johnston P, Kidd M, Middleton D et al. (1982) Analysis of HLA antigen association in proliferative diabetic retinopathy. $\mathrm{Br} \mathrm{J}$ Ophthalmol 66: 277-279

38. Rotter JI (1981) The modes of inheritance of insulin-dependent diabetes mellitus. Am J Hum Genet 33: 835-851

Received: 18 March 1993

and in revised form: 29 June 1993

Dr. L. Field

Department of Paediatrics

University of Calgary

Health Sciences Centre

3330 Hospital Drive N. W.

Calgary, Alberta

Canada $\mathrm{T} 2 \mathrm{~N} 4 \mathrm{~N} 1$ 